\title{
The paleoecology and depositional model of the Oligo-Miocene coral reefs in the Mohammad Abad Area, the West of Baft, SW Kerman, Iran
}

\author{
Fatemeh Hosseinipour \\ Payam e Noor University \\ POB 19395-4697, Tehran, Iran. E-mail: fa.Hosseinipour@gmail.com, f.hosseinipour@pnu.ac.ir
}

\begin{abstract}
This paper deals with the Oligo-Miocene coral reefs in the Mohammadabad Area, W Baft, SW Kerman. The studied coral reefs include 11 families, 25 genera and 33 species of the scleractinian corals. The coral reef successions have been deposited in three cycles on a mixed siliciclastic-carbonate platform. To understand the paleoecology, reef architecture and depositional model of the studied reefal successions, statistical analyses based on the coral niches, sedimentology analyses based on the grain size of the marly strata and microfacies analyses on limestone strata have been used. Based on the statistical analyses, the coral community includes eight ecotypes. The distribution of these ecotypes indicates that, despite of various thicknesses, and in all three coral reef successions, the branching and fast growth ecotypes are present in the basal parts and the massive, placoid and meandroid colonies are recorded in the slope, crest and distal parts of the reefs. The main disruptive phenomenon that stopped reef development and affected the reef architecture has been the addition of clastic deposits to the carbonate system. This sediment load increase is recorded as marly strata. By the addition of clastic sediment load to the system, the carbonate content of the system has been diluted, the salinity, water transparency and photic level are decreased, the favorable attachment hard substrate for coral polyps is limited, the nutrient and oxygen flux is disrupted and the coral reefs are suffocated.
\end{abstract}

KEYWORDS $\quad$ Coral reef; Paleoecology; Oligo-Miocene; Baft; Kerman.

\section{INTRODUCTION}

The geological history of the Iranian plateau mainly was affected by the collision of the Arabian and the Central Iran plates that resulted in the closure of the Neo-Tethys Ocean during the Cenozoic (Berberian and King, 1981; Berra et al., 2014; Ghasemi and Talbot, 2006; Golonka, 2004; Jafarzadeh and Hosseini-Barzi, 2007; Leturmy and Robin, 2010; McCall, 1997; Stocklin, 1968). During the Oligo-Miocene, a moderately shallow sea has born in the near volcanic arc depressions that was a part of the marine passage which connected the Mediterranean and Indo-Pacific realms during the Oligo-Miocene (Reuter et al., 2009; Zamani et al., 2010). The deposits of this sea have been named as the Qom Formation. These deposits are mainly carbonaceous with minor proportions of siliciclastic and evaporate deposits (Aghanabati, 2004). On the basis of their position relative to the Volcanic Arc, these deposits are divided into the Qom-Kashan back-arc and Isfahan-Sirjan fore-arc deposits (Reuter et al., 2009). The carbonaceous deposits of the Isfahan-Sirjan Fore-arc basin 
crop out as disjunct mountains in the Sirjan-Baft area, SE Iran. These deposits consist of thick-bedded marls, medium to thick bedded fossiliferous limestone and various sized coral reef strata. The biostratigraphy of these deposits was studied by many researchers (Amirshahkarami and Nadimi, 2016; Hamad et al., 2015; Hassani, 2012; Hassani and Vaziri, 2011; Hassani et al., 2007; Hosseinipour, 2004; Hosseinipour and Hassani, 2015; Hosseinipour et al., 2010; Mohammadi, 2014; Mohammadi and Ameri, 2015; Mohammadi et al., 2012; Mohammadi et al., 2013), but the reefal strata did not receive enough attentions. These deposits were studied in Vartun section (Rahiminejad et al., 2016), Dizlu (Yazdi et al., 2012), Khavich (Hassani et al., 2006) and Abadeh (Schuster, 2002; Schuster and Wielandt, 1999) areas. There are some coral reefs strata with various volume and thickness in the Qom formation deposits in the Sirjan-Baft area. In some cases, the coral reef layers are very thick and show complete reefal bioherms. The lower contact of the Qom Formation in the Sirjan-Baft area is sharp and the underlying units include Metamorphic rocks of the Sanandaj-Sirjan Metamorphic Belt (SSMB), volcanic units of the Urumieh-Dokhtar Volcanic Belt (UDVB) and the clastic deposits of the Lower Red Formation (LRF) respectively. The Upper contact is mostly eroded; but in the studied section, is gradually covered with the Upper Red Formation (URF) clastic deposits. The reefal strata of the Qom formation in the oil fields near the Qom area are the main reservoirs and in the Sirjan-Baft depression contain ground water. These layers also play a fundamental role in the evolution of ecosystem during the deposition of the Qom formation deposits. This paper is the first report of coral reef strata from the Sirjan-Baft area and is aimed at studying the architecture and paleoecological history of these layers.

\section{GEOLOGICAL AND GEOGRAPHICAL SETTINGS}

The studied section locates on the SW of the Kerman Province (Fig. 1A). This area is a part of the Central Iran Structural Zone between the UDVB to the E-NE and SSMB to the S-SW. The Central Iran forms a triangle region with a complex structure. Here, rocks of all ages, from the Precambrian to the Quaternary, and several episodes of orogeny, metamorphism, and magmatism can be recognized (Ghorbani, 2013). There is not a consensus regarding the boundaries of Central Iran. According to Stocklin (1968), Central Iran is bordered by the Alborz Mountains in the north, the Lut Block in the east, and Sanandaj-Sirjan in the south-southwest, whereas Nabavi (1976) considers the northern part of the Lut Block as a part of Central Iran. Nogol-e-Sadat (1993) extends the frontiers to the northeast as well as Eastern Iran and presents new subzones in his classification. In this area, the most popular outcrops include the recent alluvial deposits and the oldest unit include the purple Eocene-Oligocene clastic deposits (time equivalents to the LRF) (Fig. 1B). The studied section is located $55 \mathrm{~km}$ E of Sirjan and $41 \mathrm{~km} \mathrm{~W}$ of Baft, near the Mohammadabad Village at $56^{\circ} 10^{\prime} 46.29^{\prime \prime} \mathrm{E}$ and $29^{\circ} 18^{\prime}$ 29.57" N (Fig. 1C). At this location, the Qom formation strata crop out as light cream layers in an anticline structure (Fig. 1D, E). The stratigraphic succession of this part of the Sirjan-Baft- Khabr depression is similar to northern realms of the Qom basin, where the Qom Formation is sandwiched between the continental clastic deposits of the LRF at the base and URF at the top.

\section{MATERIALS AND METHODS}

The total thickness of studied section is $176 \mathrm{~m}$ (Fig. 2), that includes a $1 \mathrm{~m}$ thick conglomerate layer at the base, which is followed by three distinct cycles of marine carbonaceous strata. Each cycle starts with marl and marly strata succession and topped by reefal layers and fossiliferous limestone intercalations. The first cycle includes $16 \mathrm{~m}$ loose marly strata at the base and $6 \mathrm{~m}$ hard reefal limestone layers at the top. The second cycle starts with $30 \mathrm{~m} \mathrm{marl} / \mathrm{marly}$ limestone strata and ends with $8 \mathrm{~m}$ reefal limestone strata. The final cycle includes $50 \mathrm{~m}$ loose marly strata at the base and $54 \mathrm{~m}$ hard fossiliferous limestone and reefal limestone layers at the top. The final marine strata in the measured section include $8 \mathrm{~m}$ of mainly marl and silty deposits with Mollusca debris.

In the study area, the Qom Formation overlays the clastic deposits of the LRF non conformably (Fig. 3A). The upper contact is non conformable too and is covered by the terrigenous sediments of the URF (Fig. 3B). To determine the age of the section 35 hard and 33 loose samples of marly and marly limestone strata have collected. The total of 63 in situ samples of coral colonies (Fig. 3C-D) were collected from the measured section and know housed in the Payamenoor University of Kerman. The Cluster analysis method and SPSS statistics software was used to differentiate ecotypes. A data matrix, including all morphological and ecological characters of each genera, was used to cluster the identified fauna (Table 1). To find the mean grain size of the marly deposits, $300 \mathrm{gr}$ of 23 selected layers were analyzed by the Hydrometric Method in the soil mechanic laboratory of the Payamenoor University.

\section{RESULTS AND DISCUSSION}

\section{Paleoecology}

Field observations confirm that the reefal deposits in the studied section form continuous layers. The faunal 

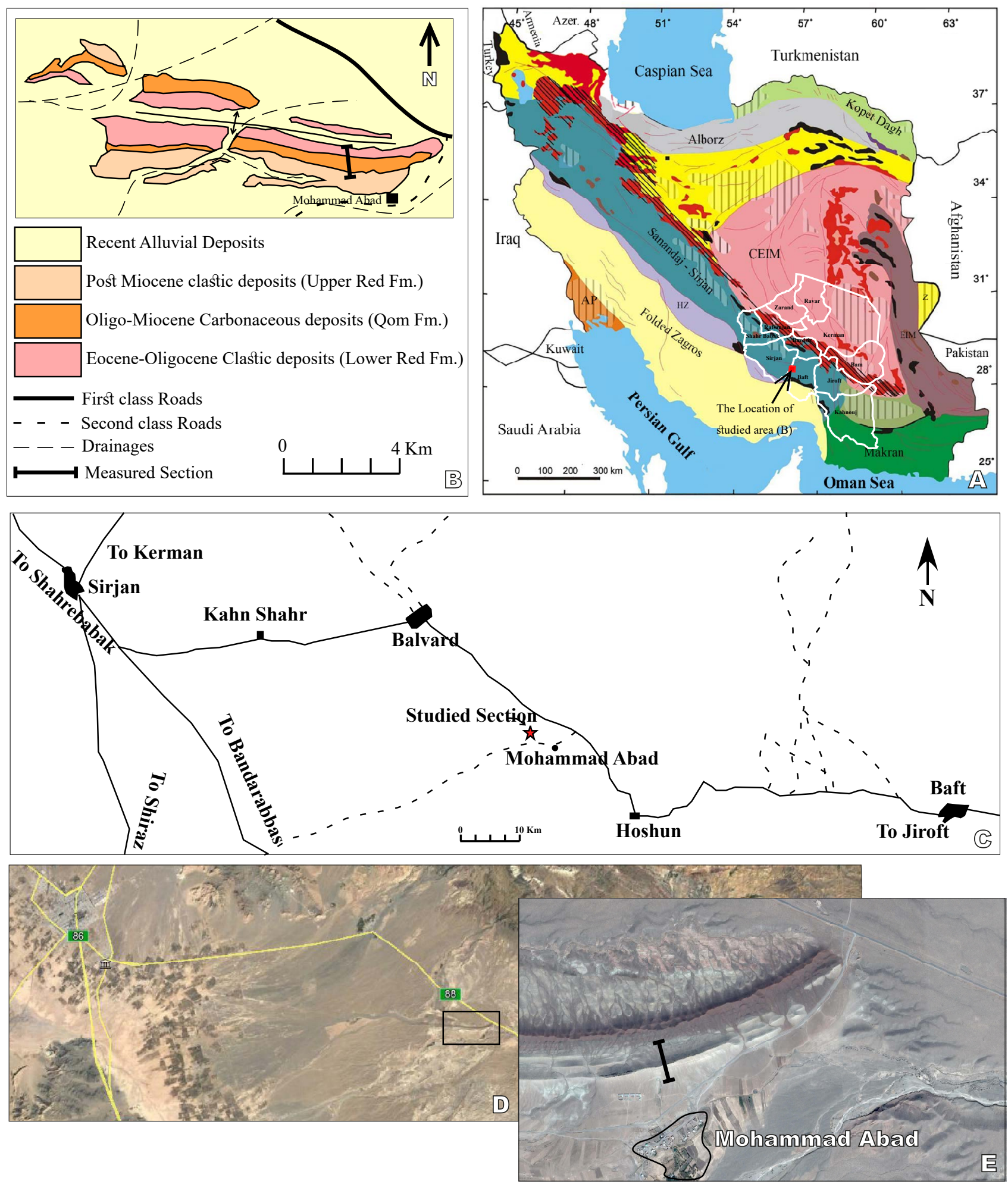

FIGURE 1. A) Structural zones of Iran (after Aghanabati, 2004) and location of the Kerman province; B) Simplified geological map of the studied area; C) Access map to the studied section; D) Satellite image of the studied area (from Google Earth); E) Satellite image of the studied section (from Google Earth). 


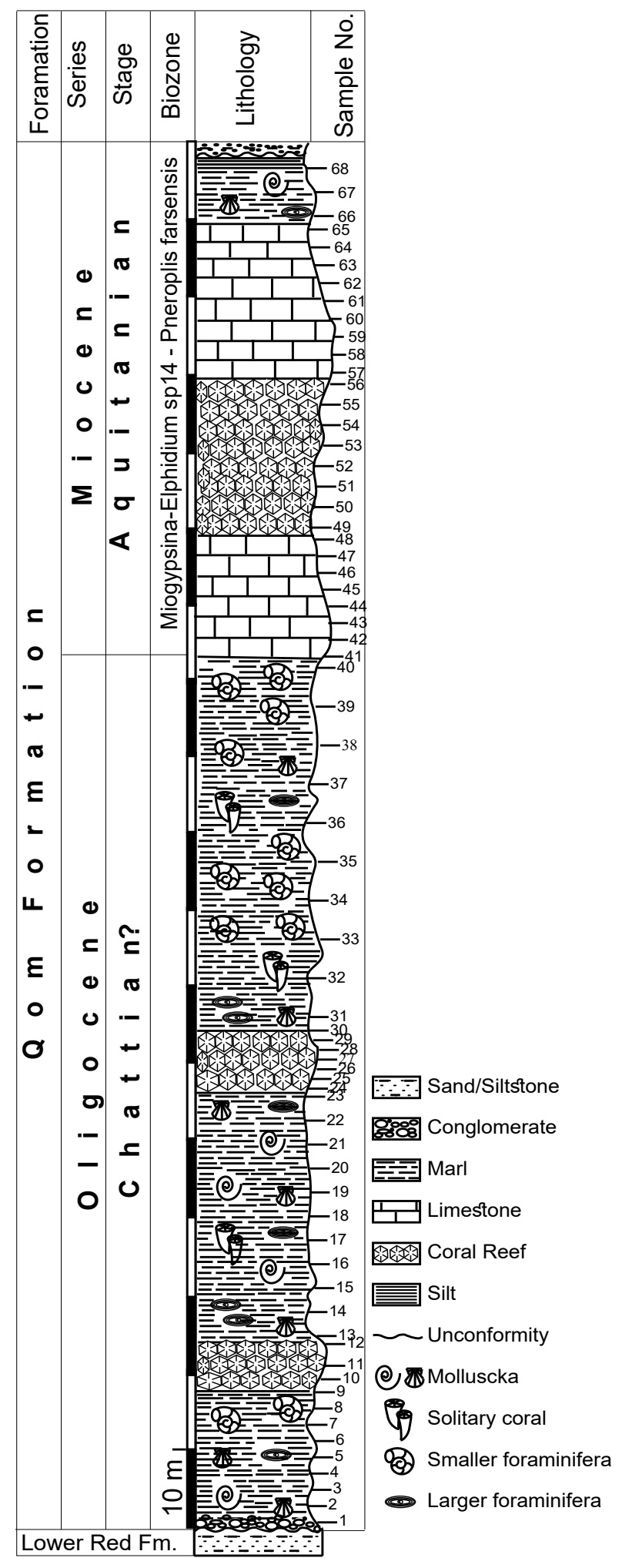

FIGURE 2. The simplified stratigraphic column of the studied section. diversity is high and includes 11 family, 25 genus and 33 species of the scleractinian corals (Table 2). The identified coral community includes fauna of both low and high energy waters, various depth, various colony forms and also solitary individuals. Clustering the identified corals based on these characters (Table 3) indicates that eight ecotypes could be distinguish in the coral community (Fig. 4).

The first ecotype includes species of Agathiphyllia, Placocoenia, Septastrea, Leptastrea, Ceriosmilia, Platycoenia, Antiguastrea, Simplastrea and Oulastrea. These faunas are mainly zoxantellate symbiotic and live in the euphotic zone. These are hermatypic, massive and mainly placoid colonies and prefer to live in mainly agitate waters near the reef crest and core (Moore, 1981; Pomar and Hallock, 2007) (Fig. 5).

The species of Acropora and Stylophora are included in the second ecotype. These branching and mainly placoid forms can be found in the moderately deep parts of the basin and basal parts of the reef body (Moore, 1981; Wallace and Bosellini, 2014; Wallace and Rosen, 2006) (Fig. 5).

The ecotype three includes the non-reef building and solitary genus, Ilariosmilia. This genus includes only one species in the studied coral community. These fauna are dominant in the bottom of the deep waters and rarely found in the main reef body (Moore, 1981; Wilson et al., 2017) (Fig. 5).

The fourth ecotype includes Favia and Astreopora. These massive, placoid and dome-shaped colonies are present in the basal and near the base of the coral reefs, in moderate depths in the low energy parts of reef body (Moore, 1981; Wilson et al., 2017) (Fig. 5).

The fifth ecotype includes massive, mainly cerioid, dome-shaped to hemispherical colonies of Favites, Goniastrea and Tarbellastrea. These fauna are the most common ones and found in the main reef body (core reef and reef crest) (Moore, 1981; Pomar and Hallock, 2007) (Fig. 5).

The species of the genus Caulastrea and Astrocoenia are assigned to the sixth ecotype. These massive, domeshaped and pedanculate fauna are adapted to live in the shallow and high energy parts of the reef body such as reef slope and reef front (Moore, 1981; Wilson et al., 2017) (Fig. 5).

The seventh ecotype includes Alveopora species. These are mainly branching, massive and cerioid corals and dominant on the reef slope in turbid waters (Moore, 1981; Wilson et al., 2017) (Fig. 5). 


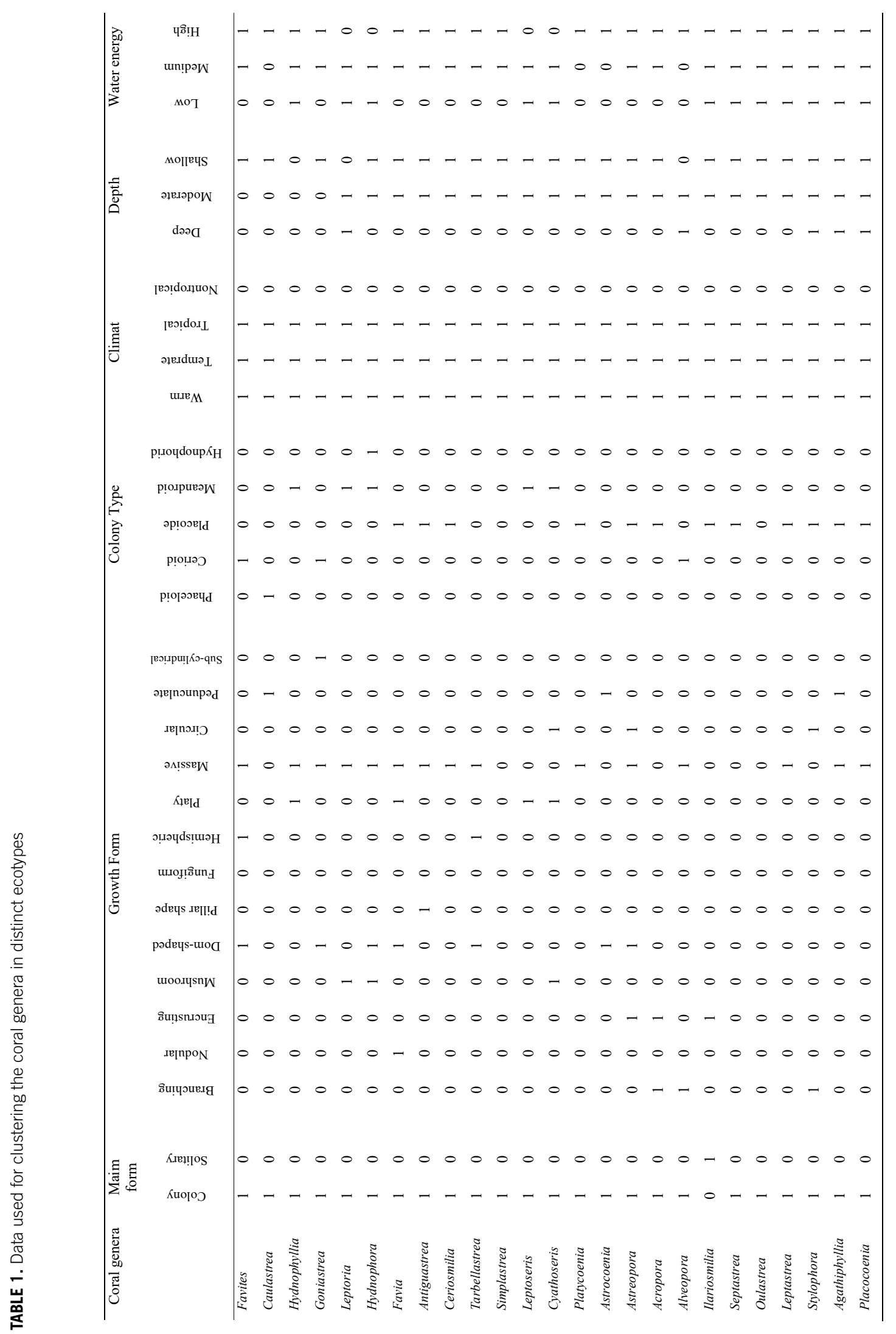



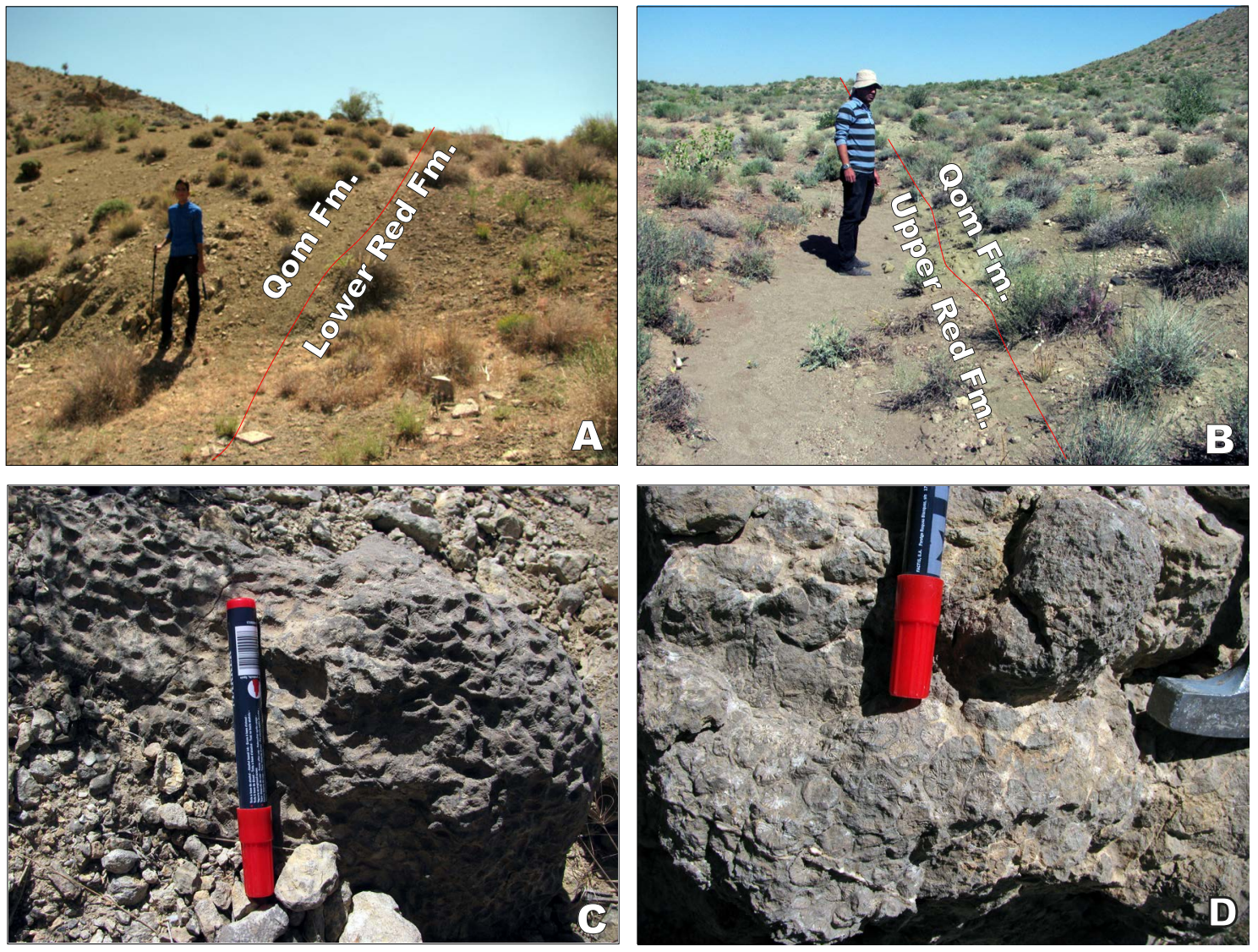

FIGURE 3. A) Lower contact of the studied section; B) Upper contact of the studied section; C, D) In-situ exposures of the coral colonies.

All species of the Leptoseris, Leptoria, Cyathoseris, Hydnophyllia and branching Hydnophora species with elongated monticles are included in the eighth ecotype. These fauna are mainly meandroid and hydnophoroid and addapted to live in various depth and light levels. In the studied reef deposits, these fauna mainly found in the protected shallow parts of the reef body (Moore, 1981; Wilson et al., 2017) (Fig. 5).

Although almost all of the identified corals are hermatypic scleractinian corals, but the distribution of them in the three studied reefal bodies is different. The differences may result from different ecological conditions in each reefal succession.

The first reefal succession in the studied section is a $6 \mathrm{~m}$ continuous layer. From the base to the top, ecotypes 2, $7+8,1+5$ and $6+8$ are seen in this succession. Based on the present ecotypes, the reef body includes thin basal and core parts, whale the distal (back reef) part is well developed. In this part of the section, there are some coral debris in the underlaying and overlaying marly strata that indicates the occurence of moderately strong submarine currents and erosion of the reef body (Fig. 6).
The second coral reef succession is thicker and more complex than the first one; having an average thickness of 8. Ecotypes $2+7,7,6+7,6,1+5$ and $4+8$ are present in this succession from the base to the top. The basal horizons of this reefal succession are not well developed and form less than the $30 \%$ of the whole thickness. About half of the succession is colonized by the reef core and crest ecotypes. It is topped by a moderately thick and homogeneous horizon of mainly back reef coral colonies. The top of the unit presents evidences of erosion (Fig. 7).

The third reefal succession is the thickest and most complete. Its average thickness is $16 \mathrm{~m}$ and is sandwiched between two fossiliferous limestone intervals. From the base to the top, ecotypes $3,2+4,6+7,2+4,6+7,6,1+5$, $6,4+8$ and 8 are represented. This coral reef succession can be divided into three distinct parts. The basal part include deep, slope and reef front colonies, the middle part include reef core and crest colonies and the upperr part include shallow and back reef colonies. The basal part is the thickest part and includes the half thickness of the whole succession. The middle and upper parts have same thickness (Fig. 8). Although there are no obvious evidences of erosion on the basal and upper contacts of the reefal 
TABLE 2. Identified coral species

\begin{tabular}{|c|c|c|}
\hline Family & Genus & Species \\
\hline \multirow{11}{*}{ Merulinidae } & & Favites sp. \\
\hline & & Favites neglecta \\
\hline & & Caulastre Pseudoflabellum \\
\hline & Caulastrea & Hydnophyllia stellate \\
\hline & Hydnophyllia & Hydnophyllia cf. fimbriata \\
\hline & Goniastrea & Goniastrea sp. \\
\hline & Leptoria & Leptoria phrygia \\
\hline & Hydnophora & Hydnophora scripta \\
\hline & & Hydnophora rudis \\
\hline & & Hydnophora sativa \\
\hline & & Hydnophora elongate \\
\hline \multirow{7}{*}{ Faviidae } & & Favia cylindracea \\
\hline & & Antiguastrea sp. \\
\hline & Antiguastrea & Antiguastrea lucasiana \\
\hline & Ceriosmilia & \\
\hline & Tarbellastrea & Ceriosmilia iranica \\
\hline & & Tarbellastrea carryensis \\
\hline & & Simplastrea cf. leytensis \\
\hline \multirow{4}{*}{ Agariciidae } & & Leptoseris alternans \\
\hline & Leptoseris & Leptoseris irregularis \\
\hline & Cyathoseris & Cyathoseris sp1. \\
\hline & & Cyathoseris sp2. \\
\hline \multirow{2}{*}{ Astrocoeniidae } & Platycoenia & Platycoenia iranica \\
\hline & Astrocoenia & Astrocoenia nana \\
\hline \multirow{3}{*}{ Acroporidae } & Astreopora & Astropora meneghiana \\
\hline & Acropora & Acropora sp. \\
\hline & Alveopora & Alveopora sp. \\
\hline Rhizangiidae & Septastrea & Septastrea sp. \\
\hline Oulastreidae & Oulastrea & Oulastrea $\mathrm{sp}$. \\
\hline Incertae Sedis & Leptastrea & Leptastrea sp. \\
\hline Pocilloporidae & Stylophora & Stylophora thirsiformis \\
\hline Agathiphyllidae & Agathiphyllia & Agathiphyllia gregaria \\
\hline Placocoeniidae & Placocoenia & Placocoenia sp. \\
\hline Smilotrochiidae & Ilariosmilia & Ilariosmilia subcurvata \\
\hline
\end{tabular}


TABLE 3. Distinguished ecotypes, their taxa, colony form, ecology and symbol

\begin{tabular}{|c|c|c|c|c|}
\hline $\begin{array}{l}\text { Ecotype } \\
\text { No. }\end{array}$ & Fauna & Colony Form & Ecosystem & Symbol \\
\hline 1 & $\begin{array}{l}\text { Agathiphyllia,Placocoenia, } \\
\text { Septastrea, Leptastrea, } \\
\text { Ceriosmilia, Platycoenia, } \\
\text { Antiguastrea, Simplastrea, } \\
\text { Oulastrea }\end{array}$ & $\begin{array}{l}\text { Massive, } \\
\text { Hermatypic, } \\
\text { mainly Placoid }\end{array}$ & $\begin{array}{l}\text { Euphotic zone in } \\
\text { the reef crest } \\
\text { and core }\end{array}$ & \\
\hline 2 & Acropora, Stylophora & $\begin{array}{l}\text { Branching } \\
\text { Hermatypic } \\
\text { mainly placoid }\end{array}$ & $\begin{array}{l}\text { Euphotic zone in } \\
\text { the reef base at } \\
\text { the deeper } \\
\text { waters }\end{array}$ & \\
\hline 3 & Ilariosmilia & $\begin{array}{l}\text { Solitary } \\
\text { a-hermatypic }\end{array}$ & $\begin{array}{l}\text { Deep waters } \\
\text { Rare in the main } \\
\text { reef body }\end{array}$ & \\
\hline 4 & Favia, Astreopora & $\begin{array}{l}\text { massive, } \\
\text { placoid } \\
\text { Hermatypic } \\
\text { dome-shaped }\end{array}$ & $\begin{array}{l}\text { Euphotic zone in } \\
\text { the low energy } \\
\text { and non agitated } \\
\text { waters }\end{array}$ & \\
\hline 5 & $\begin{array}{l}\text { Favites, Goniastrea, } \\
\text { Tarbellastrea }\end{array}$ & $\begin{array}{l}\text { Hermatypic } \\
\text { massive, } \\
\text { mainly cerioid, } \\
\text { dome-shaped to } \\
\text { hemispherical }\end{array}$ & $\begin{array}{l}\text { Common in the } \\
\text { various reef } \\
\text { ecosystems }\end{array}$ & \\
\hline 6 & Caulastrea, Astrocoenia & $\begin{array}{l}\text { Massive } \\
\text { dome-shaped } \\
\text { pedunculate } \\
\text { Hermatypic }\end{array}$ & $\begin{array}{l}\text { Euphotic zone } \\
\text { Shallow and } \\
\text { high energy } \\
\text { parts in the reef } \\
\text { front and reef } \\
\text { slope }\end{array}$ & \\
\hline 7 & Alveopora & $\begin{array}{l}\text { Hermatypic } \\
\text { Branching- } \\
\text { massive } \\
\text { Cerioid }\end{array}$ & $\begin{array}{l}\text { Euphotic zone } \\
\text { At the turbid } \\
\text { waters on the } \\
\text { reef slope }\end{array}$ & \\
\hline 8 & $\begin{array}{l}\text { Leptoseris, Leptoria, } \\
\text { Cyathoseris, Hydnophyllia }\end{array}$ & $\begin{array}{l}\text { Massive, } \\
\text { Hermatypic } \\
\text { meandroide and } \\
\text { hydnophoride }\end{array}$ & $\begin{array}{l}\text { Euphotic zone } \\
\text { protected low } \\
\text { energy and } \\
\text { shallow parts of } \\
\text { the reef }\end{array}$ & \\
\hline
\end{tabular}




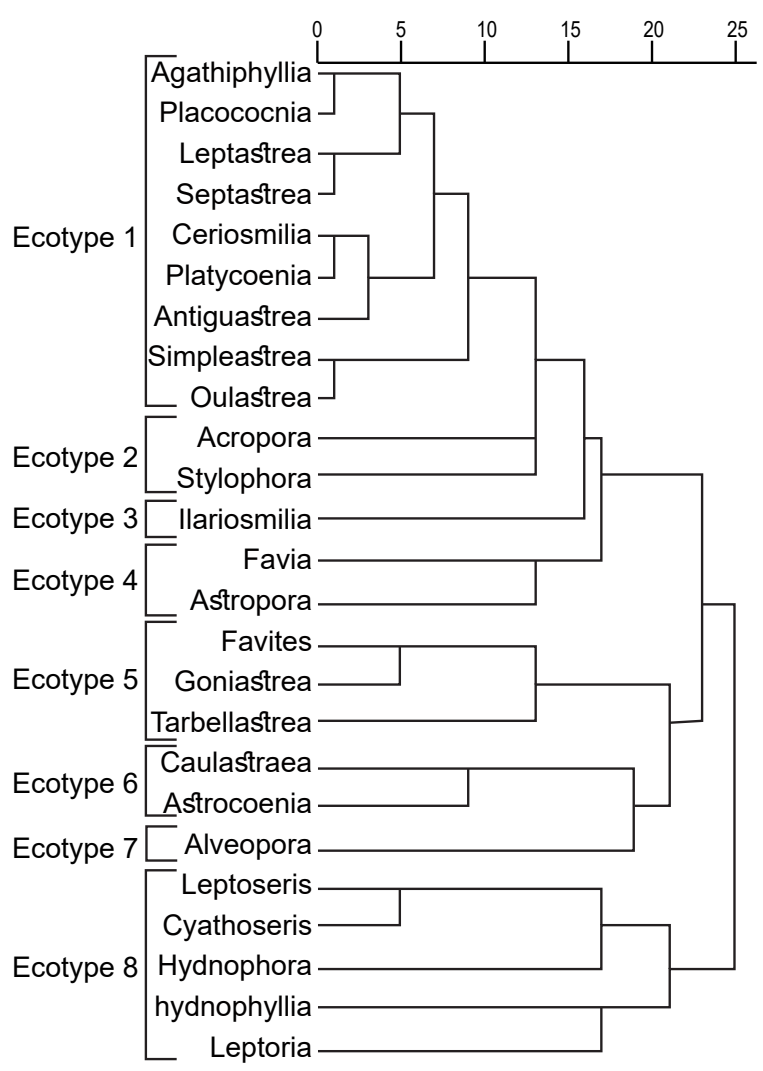

FIGURE 4. Dendrogram of the eight ecotypes. succession, the presence of coral floatstone microfacies in the adjacent limestone strata points to the abrasion of some marginal layers of the main reef body.

\section{Microfacies and sedimentary analysis}

Two limestone intervals are present below and above the third reefal succession and include the following microfacies. The most common allochemical particles include peloids, benthic foraminifera (Rotalia, Nephrolepidina, Ammunia, Elphidium, Miogypsinidae and Textularids) and ostracods tests, molluscan (mainly Bivalvia) debris, bryozoans, algae and coral particles. The texture of the limestone microfacies varies from wackestone to condensed packestone grainstone, floatstone, rudstone and framestone. Based on the allochemical particles present and texture six microfacies have been distinguished (Fig. 9) and summarized in the Table 4.

The marly deposits of the studied section are divided into three types based on their faunal content and mean grain size. The first marl type mainly deposited in the basal and final layers of the section. The faunal content of these deposits includes Elphidium spp. rare biserial agglutinate foraminifera and extremely rare miliolidae. This faunal content reflects that these layers are deposited in near shore and brackish waters (BouDagher-Fadel and Lokier, 2005; BouDagherFadel, 2008). The mean grain size of these deposits is 1.0$0.30 \mathrm{~mm}$ that covers the coarse to fine grain sand size.

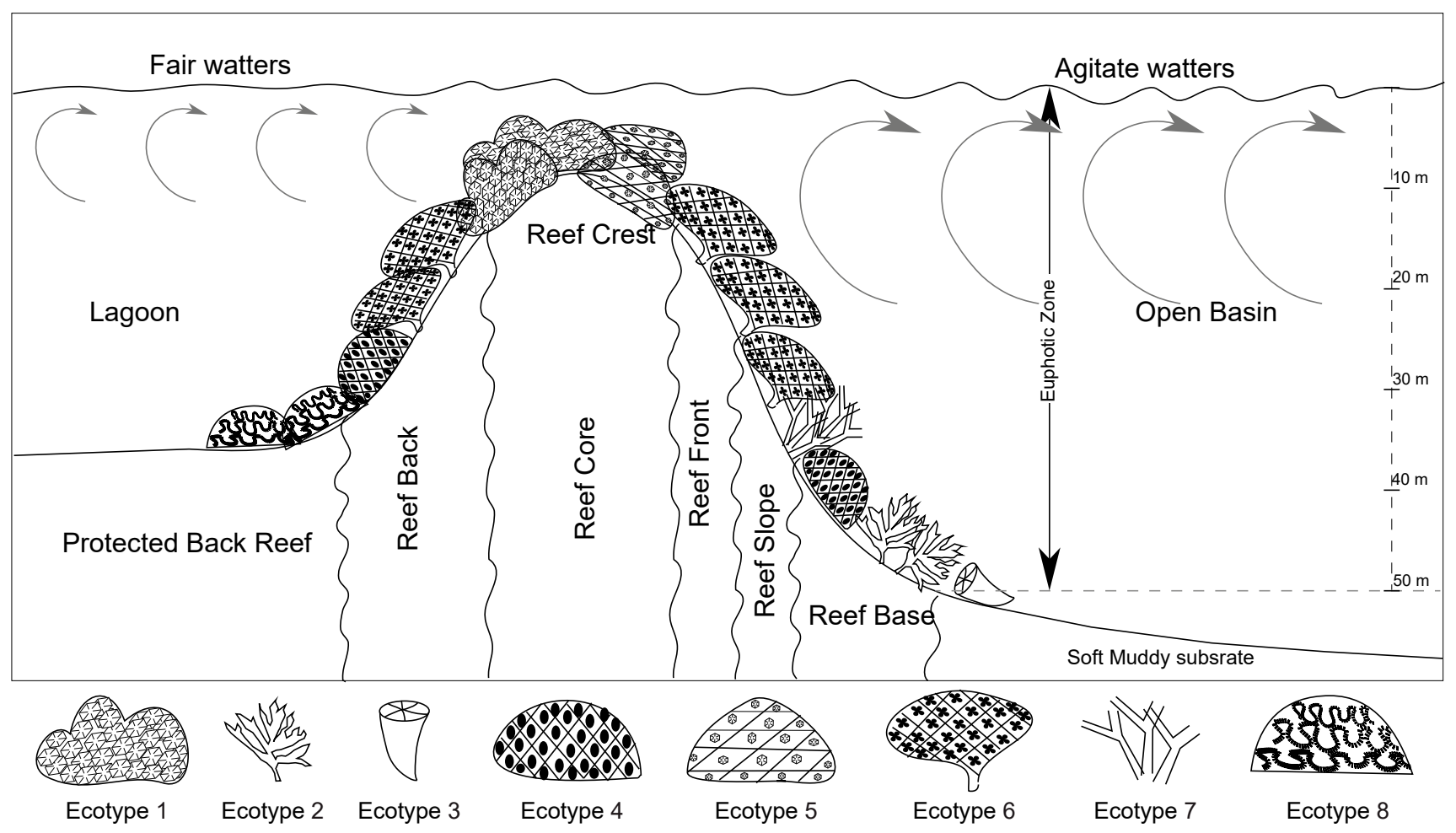

FIGURE 5. Ecological and architectural position of the distinguished ecotypes. 


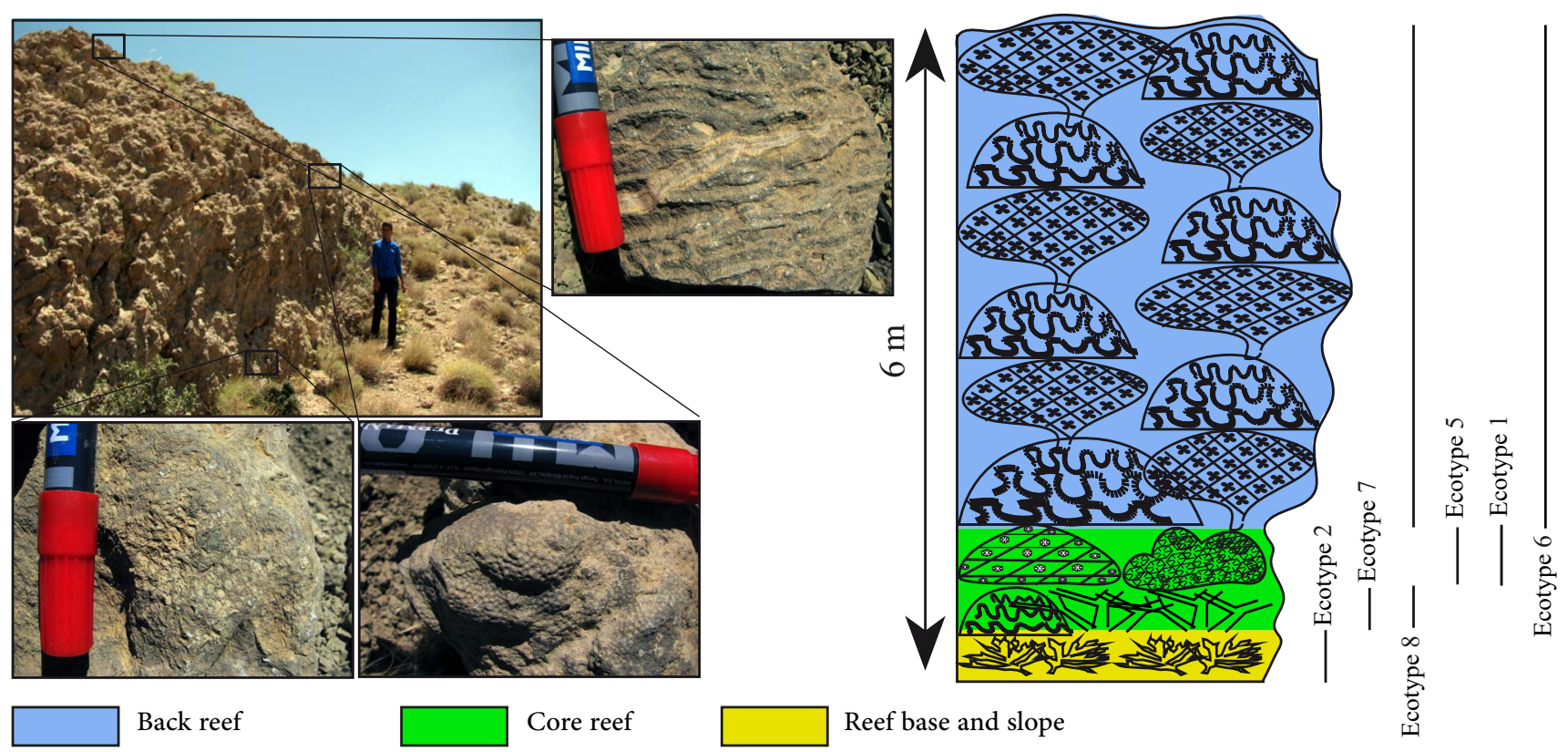

FIGURE 6. Outcrop of the first coral succession (left) and distribution of present ecotypes (right). See Table 3 for legend of symbols.
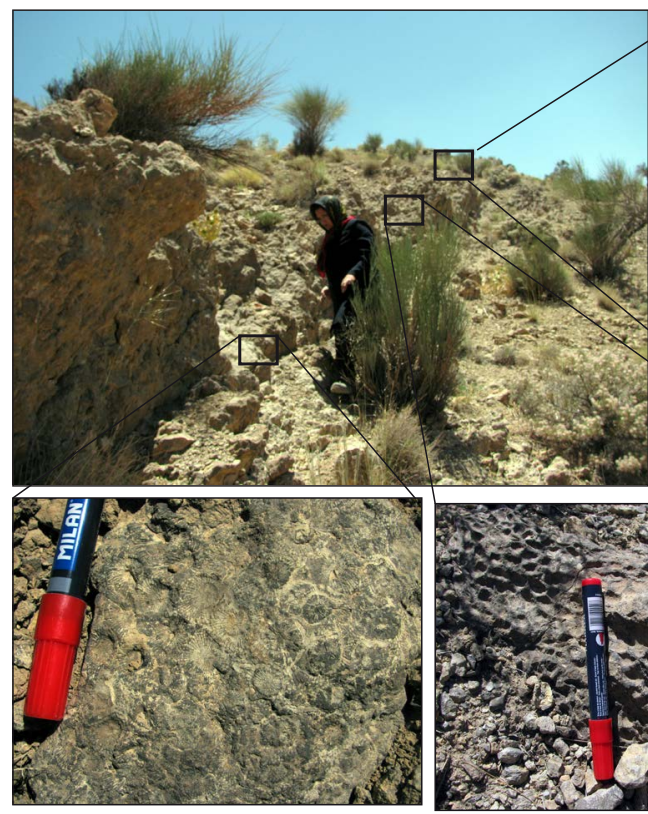

Back reef
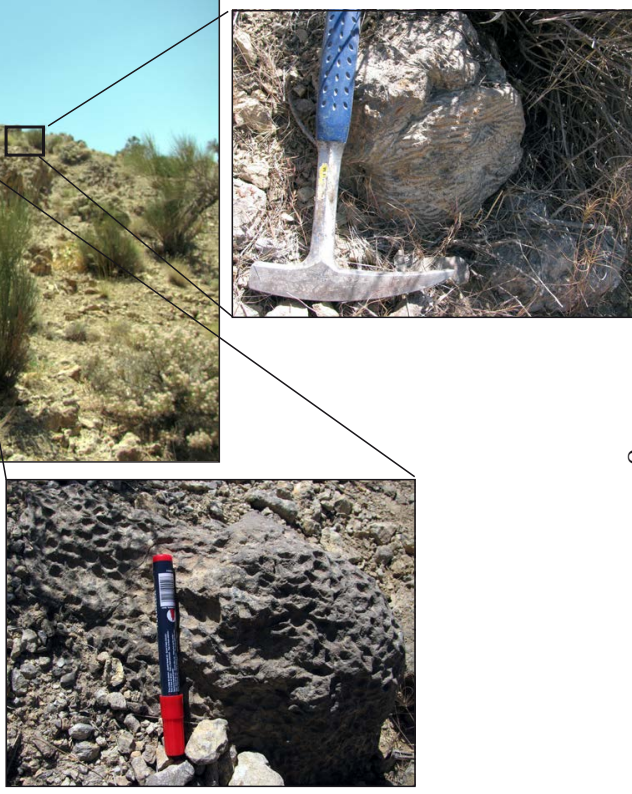

Core reef
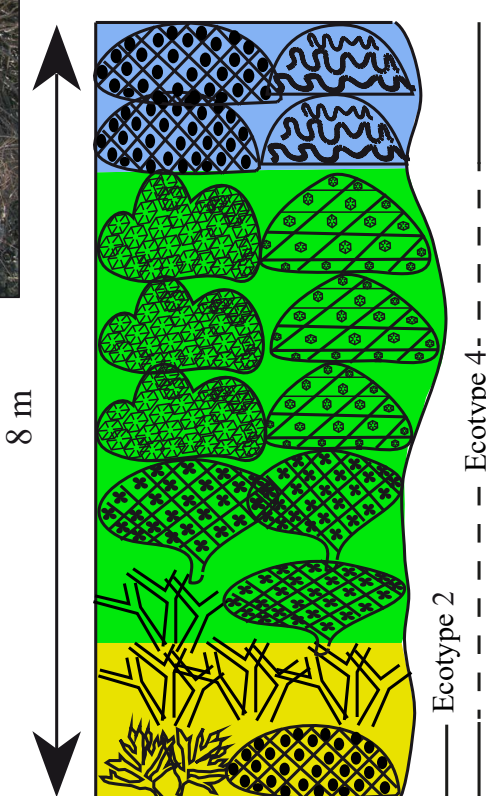

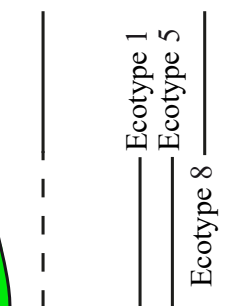$$
6
$$$$
\sum_{0}^{\infty}
$$$$
\text { - }
$$$$
1 \text { 胥 }
$$

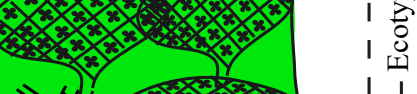$$
11 \ldots
$$$$
\text { (1) }
$$

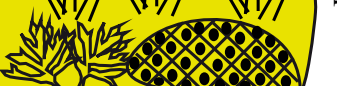

Reef base and slope

FIGURE 7. Outcrop of the second coral succession on the field (left) and distribution of present ecotypes (right). See Table 3 for legend of symbols. 
TABLE 4. Identified carbonate microfacies in the studied section

\begin{tabular}{|c|c|c|c|c|}
\hline 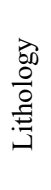 & 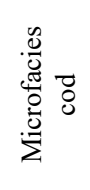 & 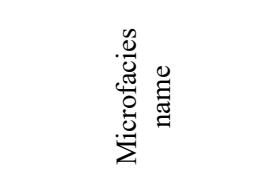 & 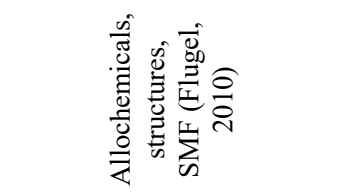 & 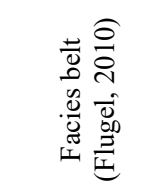 \\
\hline \multirow{6}{*}{$\begin{array}{l}\stackrel{\Xi}{0} \\
\text { 㺃 } \\
\stackrel{0}{\Xi}\end{array}$} & L1 & $\begin{array}{l}\text { Bioclast } \\
\text { wack/packstone }\end{array}$ & $\begin{array}{l}\text { Ostracoda and smaller } \\
\text { foraminifera tests, SMF } \\
\text { No. } 2\end{array}$ & $\begin{array}{l}\text { deep parts of } \\
\text { the basin }\end{array}$ \\
\hline & L2 & $\begin{array}{l}\text { Bioclast Miogypsina } \\
\text { wackstone }\end{array}$ & $\begin{array}{l}\text { Miogypsinidae, } \\
\text { foraminifera and molluscan } \\
\text { shell debris, SMF No.8-9 }\end{array}$ & $\begin{array}{l}\text { moderately } \\
\text { deep shelf } \\
\text { below the } \\
\text { wave } \\
\text { effected } \\
\text { depth }\end{array}$ \\
\hline & L3 & $\begin{array}{l}\text { Coral } \\
\text { rudstone/floatstone }\end{array}$ & coral debris, SMF No.5 - 6 & $\begin{array}{l}\text { fore slope of } \\
\text { the marginal } \\
\text { reef setting }\end{array}$ \\
\hline & L4 & Coral boundstone & $\begin{array}{l}\text { Various coral frameworks, } \\
\text { SMF7 }\end{array}$ & marginal reef \\
\hline & L5 & $\begin{array}{l}\text { Algal bryozoan } \\
\text { rudstone/grainstone }\end{array}$ & $\begin{array}{l}\text { large bryozoan } \\
\text { (Tubucellaria) and algae } \\
\text { (Archaeo- lithothamnium) } \\
\text { debris, SMF5 }\end{array}$ & $\begin{array}{l}\text { marginal } \\
\text { back reef and } \\
\text { sand shoals }\end{array}$ \\
\hline & L6 & $\begin{array}{l}\text { Fossiliferous peloid } \\
\text { wackstone/packstone }\end{array}$ & $\begin{array}{l}\text { Benthonic foraminifera } \\
\text { (Miliolidae, Alveolinidae, } \\
\text { Rotalia, Nephrolepidina, } \\
\text { Ammunia, Elphidium and } \\
\text { Textularids) tests, peloid } \\
\text { Mollusca and echinoderm } \\
\text { debris, SMF No.10 }\end{array}$ & $\begin{array}{l}\text { non- } \\
\text { restricted to } \\
\text { restricted } \\
\text { lagoon }\end{array}$ \\
\hline
\end{tabular}

The second marl type contains mainly miliolidae, biserial agglutinate benthic foraminifera and rare Borelis tests. These layers are light green to cream in color and mainly present in the upper part of the section. The grain size range of these deposits indicates that these deposits consist of fine sand to silt $(0.25$ to $0.0075 \mathrm{~mm})$ grains

The third type includes dark green to gray deposits with smaller and moderately deep benthonic foraminifera such as Cibicidoides and Bolivina. These layers also contain smooth and no ornamented ostracoda and echinoderm spines. The grain size is 0.0085 to $0.0030 \mathrm{~mm}$, falling within the clay size range.

The main mineralogy of the marly strata includes quartz, mica, rare feldspars, heavy minerals and clay. This mineral content is very similar to the main mineralogy of the Sanandaj Sirjan Metamorphic Belt and Uromieh-Dokhtar Volcanic Belt rocks, which means that these zones were the source of the siliciclastic fraction of these sediments.

In general, the main lithology of the studied succession suggests a mixed carbonate-siliciclastic marginal shelf setting. The grain size analysis and faunal content of the marly strata indicate that a significant clastic supply contributed to the carbonate environment during at least four major phases and corresponding to the marly units (Fig. 10). In fact, the carbonate sediments of the environment have diluted by the addition of these sediments. In a brief context, deposition of the marly strata on the carbonaceous platforms would be a result of the extraordinary increase in activity of rivers in response to the climatic changes or increasing the sediment supply by continental uplifting (Einsele, 1982; Miall, 1984; Miall and Tyler, 1991; Pomar et al., 2002; Westphal, 2006; Westphal and Munnecke, 2003). Beside the deposition of marly strata, because of the extraordinary addition of freshwater, the salinity of sea water has decrease. The addition of the fine grained load decrease the transparency and light level, diluted the sedimentary carbonate content and the standard marine condition has interrupted (Wilson et al., 2017).

In fact, corals are very sensitive creatures (Mewis and Kiessling, 2012). The juvenile forms of corals could not be preserved and growth in harsh environments and the large and continuous coral reefs are developed in clear, warm and 


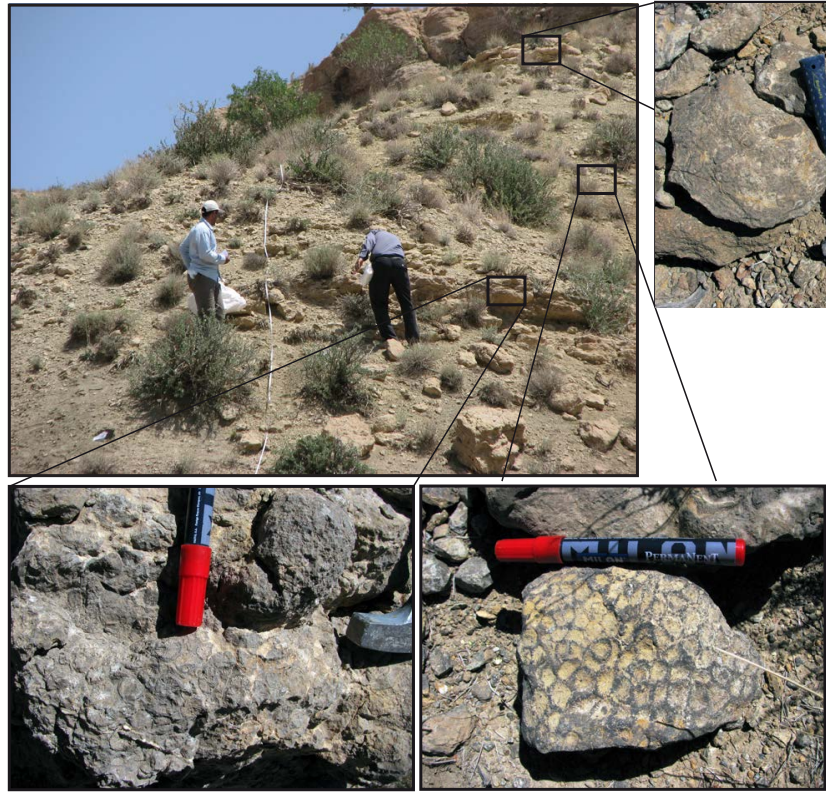

$\square$ Back reef Core reef Reef base and slope

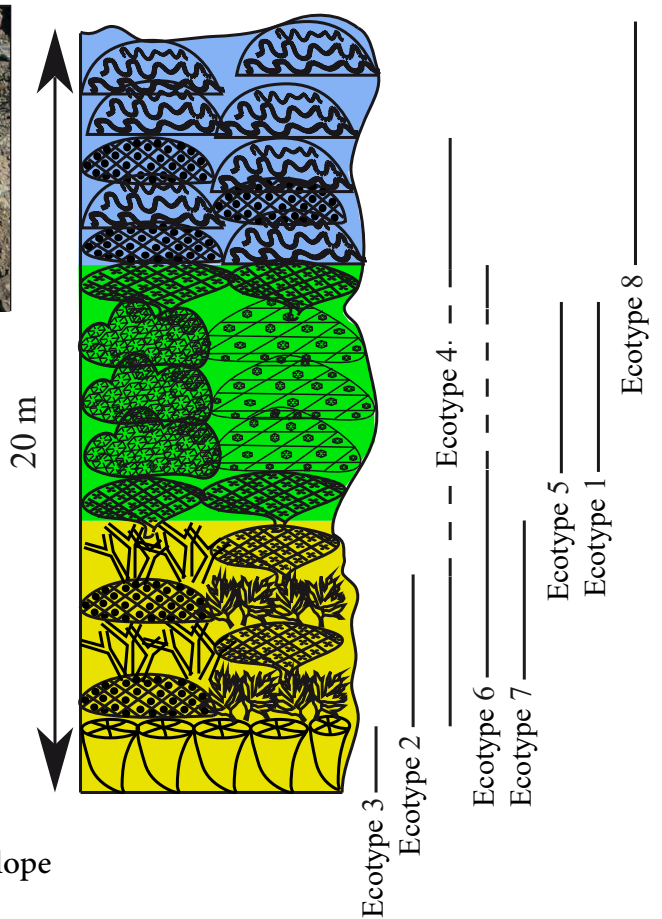

FIGURE 8. Outcrop of the third coral succession on the field (left) and distribution of present ecotypes (right). See Table 3 for legend of symbols.
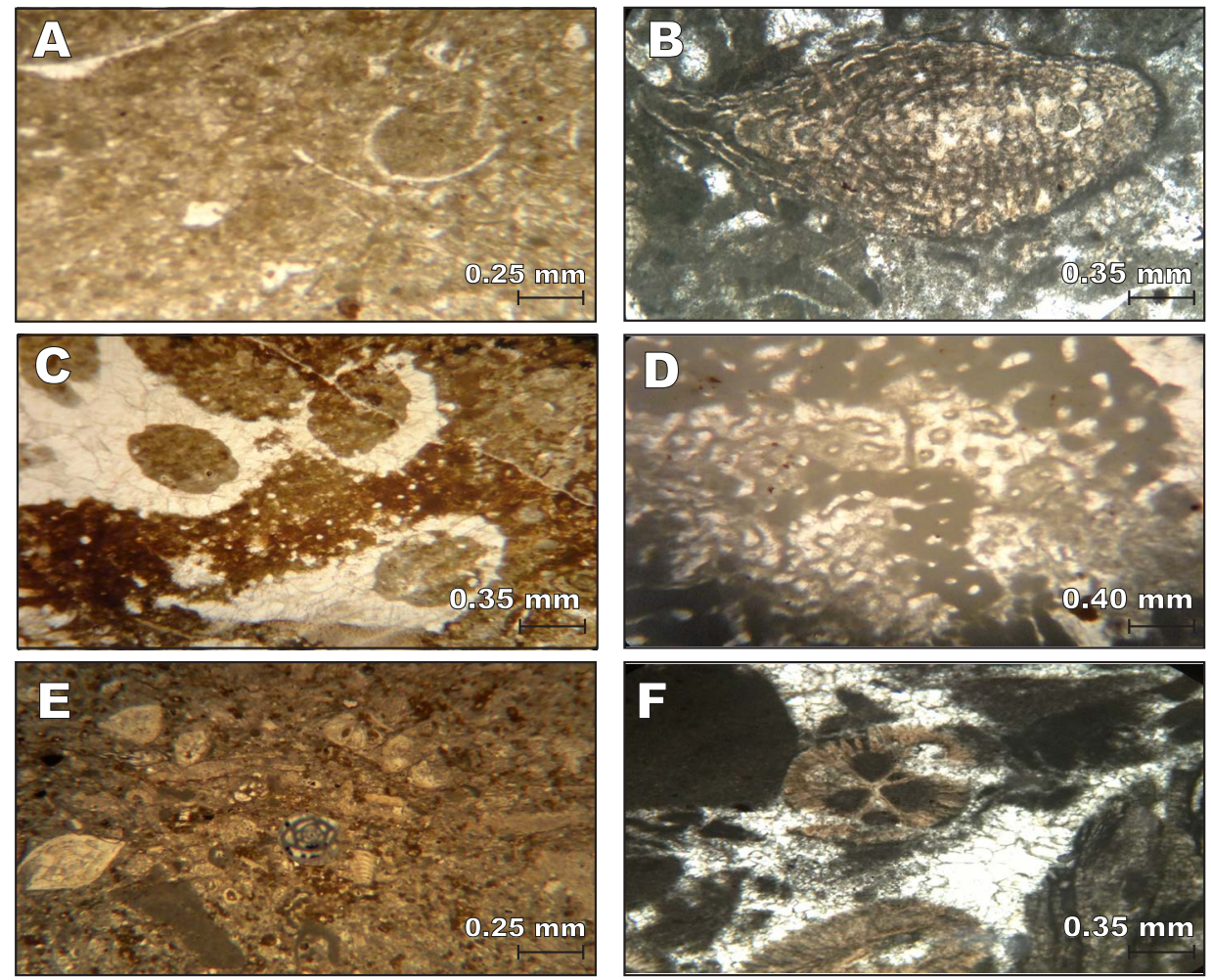

FIGURE 9. Microphotographs of the identified microfacies; A) Bioclast wack/packstone (L1); B) Bioclast Miogypsina wackstone (L2); C) Coral rudstone/floatstone (L3); D) Coral Boundstone (L4); E) Algal bryozoan rudstone/grainstone (L5); F) Fossiliferous Pelloid Wackstone/Packstone (L6). 


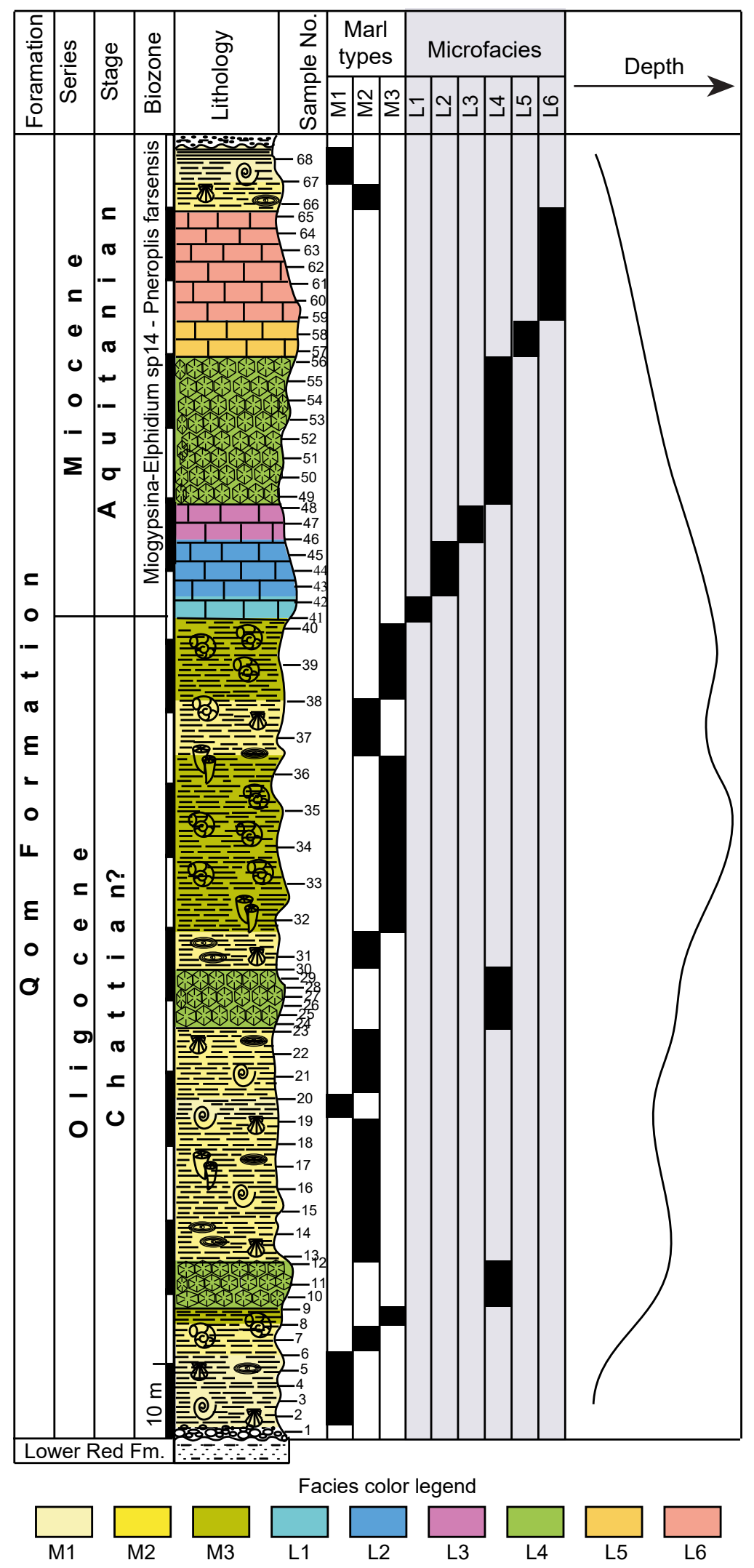

FIGURE 10. Distribution patterns of the marl types and microfacies along the stratigraphic column of the studied section. 
normal saline waters in the euphotic zone on stable platforms (Hoogenboom and Connolly, 2009; Mewis and Kiessling ,2012; Wilson et al., 2017). Because of the importance of symbiotic algae in the coral reef development, the high light level and water clarity are vital factors for reef colonies.

The taphonomic preservation of the corals in geological records depends on some intrinsic and extrinsic factors. The main intrinsic factors include growth rate and colony form and size (Greenstein, 2007; Hoogenboom and Connolly, 2009) and the main extrinsic factors are water energy and agitation, nutrient and oxygen supply, light level, salinity and temperature (Greenstein, 2007). The branching corals are more sensitive to water energy and light but their regeneration and growth rate is higher than the massive ones (Greenstein, 2007). In comparison to branching corals, the agitation and water energy tolerance of massive colonies is higher but their growth and regeneration rate is lower (Greenstein, 2007). Therefore, in almost all typic reefal deposits, the base of the reef body consists of branching colonies that means the prevalence of favorable ecological factors (Greenstein, 2007). Also, in the studied reefal deposits, the base of all three coral reef successions was made of branching colonies (ecotypes 2 and 7). This solid framework was the basis for the development of the different parts of reef body (slope, core and crest and back reef) by increasing the stable attach area for the coral polyps (Greenstein, 2007). In the first and second reefal succession punctuated stability episodes allowed the reef development, but the ecosystem stability was not long enough to develop thick reefal and limestone layers. In the case of the studied area, the main cause of ecosystem instability has been the addition of the clastic input to the carbonate system. By the addition of this clastic sediment input, the salinity and water transparency are reduced, the euphotic zone narrows, the hard attachment basements are buried and nutrient/oxygen flux is disturbed. In fact, the first and second coral reefs are suffocated under the marly strata. In comparison to the first and second coral reefs, the third one has deposited during a moderately longer period of ecosystem stability. The lower $15 \mathrm{~m}$ of limestones, the following $20 \mathrm{~m}$ of reef strata and the upper $19 \mathrm{~m}$ of limestones indicate that carbonate system was not aborted by the influx of clastic sediments. The reef architecture in the third reef succession starts with the basal branching ecotypes and follows by other massive colonies. The reef base, slope, crest, core and back reef of this coral reef are well developed. The facies changes in this part of the section suggests the gradual sea level fall and upward shallowing of the whole system (Fig. 10).

\section{CONCLUSION}

The coral reefs in the Mohammad Abad section (176m, Qom Formation, Oligo-Miocene), W Baft, SW Kerman, are deposited in three cycles. The coral reef community includes 11 Families, 25 genus and 33 species. Based on the ecological studies, the coral community includes eight ecotypes. The distribution of these ecotypes in three coral cycle shows that each cycle has started by the branching corals, which are faster in regeneration and growth, as the hard basis for the overlaying massive corals. Each coral reef cycle includes distinct proximal, crest, core and distal parts with special adopted ecotypes. The lithological state of the coral reef cycles in the studied area indicated that the main ecological distortions factor, which aborted the coral's favorable ecosystem, was the increase of fluvial discharge and clastic sediment supply to the carbonate system. This activation of continental runoff changed the salinity to brackish waters, diluted the carbonate content, decreased the transparency and light level, limited the hard attach basements for coral polyps and suffocated the young coral colonies. The sedimentological expression of this increase of sediment flux is the thick marly strata with similar mineralogy to the SSMB and UDVB units. When the deposition of marly strata stopped, the coral growth resumed and the reef ecosystem developed. This favorable carbonate system is stronger in the final phase of the basins evolution that resulted to the deposition of moderately thick limestone and coral reef succession. Based on the presence of hermatypic scleractinian corals in the studied area, the main ecosystem located in a shallow, warm and nonagitated sea.

\section{REFERENCES}

Aghanabati, A., 2004. Geology of Iran. Tehran, Geological Survey of Iran, 586pp.

Amirshahkarami, M., Nadimi, M., 2016. Paleoecology and biostratigraphic data of the large benthic foraminifera in the Oligocene-Miocene Qom Formation in Kahak area, in the Urumieh-Dokhtar province in Iran. Journal of Stratigraphy and Sedimentology Researches, 32, 91-108.

Berberian, M., King, G.C.P., 1981. Towards a paleogeography and tectonic evolution of Iran. Canadian Journal of Earth Sciences, 18, 210-265.

Berra, F, Angiolini, L., Muttoni, G., 2014. The Evolution of the Tethys Region throughout the Phanerozoic: A Brief Tectonic Reconstruction. In: Marlow, L., Kendall, C., Yose, L. (eds.). Petroleum systems of the Tethyan region. American Association of Petroleum Geologist (AAPG), 106 (Memoir), 1-27. DOI: $10.1306 / 13431840 \mathrm{~m} 1063606$

BouDagher-Fadel, M., Lokier, S.W., 2005. Significant Miocene larger foraminifera from South Central Java. Genève, Revue de Paléobiologie, 24, 291-309.

BouDagher-Fadel, M.K., 2008. Evolution and geological significance of larger benthic foraminifera. Developments in Palaeontology \& Stratigraphy Netherlands, Elsevier, 21, 544pp. 
Einsele, G., 1982. Limestone-marl cycles (periodites): diagnosis, significance, causes-a review. In: Einsele, G., Seilacher, A. (eds.). Cyclic and event stratification. Berlin, Springer, 8-53.

Ghasemi, A., Talbot, C.J., 2006. A new tectonic scenario for the Sanandaj-Sirjan Zone (Iran). Journal of Asian Earth Sciences, 26, 683-693. DOI: 10.1016/j.jseaes.2005.01.003

Ghorbani, M., 2013. Economic geology of Iran. Netherlands, Springer, 581pp.

Golonka, J., 2004. Plate tectonic evolution of the southern margin of Eurasia in the Mesozoic and Cenozoic. Tectonophysics, 381, 235-273. DOI: 10.1016/j.tecto.2002.06.004

Greenstein, B.J., 2007. Taphonomy: Detecting Critical Events in Fossil Reef-Coral Assemblages. In: Aronson, R.B. (ed.). Geological Approaches to Coral Reef Ecology. Berlin, Springer, 31-60.

Hamad, M.M., El Gammal, R., Nouradini, M., 2015. Coralline Red Algae From The Early Miocene Qom Formation, Bagh Section, Northern Isfahan, Iran. Australian Journal of Basic and Applied Sciences, 9, 467-480.

Hassani, M.J., Vaziri, M.R., Dastanpour, M., Kheradmand, A., Tavafianzadeh, M., 2006. The study of some Upper OligoceneLower Miocene corals of southern Sirjan. In: Hamdi, B., Aghanabati, A. (eds.). 24th symposium on Goscience. Thehran, Geological Survey of Iran, 264-270.

Hassani, M.J., Vaziri, M.R., Dastanpour, M., Kheradmand, A., Tavafianzadeh, M., 2007. Biostratigraphy and paleoecology of the Oligo-Miocene deposits in the Kuh-e-Khavich area, S Sirjan. In: Dastanpour, M., Aryaee, A. (eds.). First conference of the Iranian Paleontological Society. Tehran, Iranian Paleontological Society, 69(1), 23-27.

Hassani, M.J., Vaziri, M.R., 2011. Early-Miocene Gastropods from Khavich Area, South of Sirjan, (Kerman, Iran). Islamic Republic of Iran, Biostratigraphy, Paleogeography and Paleoecology Journal of Sciences, 22, 125-133.

Hassani, M-J., 2012. Biostratigraphy, paleoecology and chemostratigraphy of the Qom Formation deposits in Kerman Province. Ph. Doctoral Thesis. Shahid Bahonar University of Kerman, 127pp.

Hoogenboom, M.O., Connolly, S.R., 2009. Defining fundamental niche dimensions of corals: synergistic effects of colony size, light, and flow. Ecology, 90, 767-780.

Hosseinipour, F, 2004. The study of biostratigraphy and paleoecology of Oligo-Miocene deposits at Nort and East of the Sirjan. MsC. Thesis. Shahid Bahonar University of Kerman, 174pp.

Hosseinipour, F, Vaziri, M.R., Hassani, M.J., 2010. Oligo-Miocene ostracoda and their paleoecology in the Bujan Area, Sirjan Sedimentary Facies, 2, 163-172.

Hosseinipour, F, Hassani, M.J., 2015. Biostratigraphy and paleoecology of Upper Paleocene to Lower Oligocene deposits in Southeast of the Hajiabad Area (Zagros Basin, SW Iran) Arabian Journal of Geosciences, 8, 8295-8312. , DOI:10.1007/s12517-015-1778-7.

Jafarzadeh, M., Hosseini-Barzi, M., 2007. Petrography and geochemistry of Ahwaz Sandstone Member of Asmari Formation, Zagros, Iran: implications on provenance and tectonic setting Revista Mexicana de Ciencias Geológicas, 25, 247-260.

Leturmy, P., Robin, C., 2010. Tectonic and Stratigraphic Evolution of Zagros and Makran during the Mesozoic - Cenozoic. Geological Society, London, 330, 1-4.

McCall, G.J.H., 1997. The geotectonic history of the Makran and adjacent areas of southern Iran Journal of African Earth Soences, 15, 517-531.

Mewis, H., Kiessling, W., 2012. Environmentally controlled succession in a late Pleistocene coral reef (Sinai, Egypt) Coral Reefs, 32, 49-58. DOI:10.1007/s00338-012-0968-y.

Miall, A., 1984. Principles of sedimentary Basin Analysis. Springer Science+ Business Media, LLC, New York, 282pp.

Miall, A.D., Tyler, N., 1991. The three-dimensional facies architecture of terrigenous clastic sediments and its implications for hydrocarbon discovery and recovery. SEPM (Society for Sedimentary Geology), USA, 3, 1-2. DOI: https://doi.org/10.2110/csp.91.03.

Mohammadi, E., Hasanzadeh-Dastgerdi, M., Ghaedi, M., Dehghan, R., Safari, A., Vaziri-Moghaddam, H., Baizidi, C., Vaziri, M.R., Sfidari, E., 2012. The Tethyan Seaway Iranian Plate Oligo-Miocene deposits (the Qom Formation): distribution of Rupelian (Early Oligocene) and evaporate deposits as evidences for timing and trending of opening and closure of the Tethyan Seaway. Carbonates and Evaporites, 28, 321-345. DOI:10.1007/s13146-012-0120-7

Mohammadi, E., Vaziri, M-R., Dastanpour, M., 2013. Biostratigraphy of the nummulitids and lepidocyclinids bearing Qom Formation based on larger benthic foraminifera (Sanandaj-Sirjan fore-arc basin and Central Iran back-arc basin, Iran). Arabian Journal of Geosciences, 8, 403-423. DOI:10.1007/s12517-013-1136-6.

Mohammadi, E., 2014. Systematics and paleoecology of the ostracods and foraminifera of the Oligo-Miocene Qom Formation in Qom and Esfahan-Sirjan sedimentary basins. PhD. Thesis. Shahid Bahonar University of Kerman. 267pp.

Mohammadi, E., Ameri, H., 2015. Biotic components and biostratigraphy of the Qom Formation in northern Abadeh, Sanandaj-Sirjan fore-arc basin, Iran (northeastern margin of the Tethyan Seaway) Arabian Journal of Geosciences, 8, 10789-10802. DOI:10.1007/s12517-015-1948-7.

Moore, R.C., 1981. Treatise on Invertebrate Paleontology Part F Coelenterata Supplement 1. University of Kansas Press, USA, 762pp.

Nabavi, M.H., 1976. An introduction to the geology of Iran. Geological survey of Iran, Tehran, 109pp.

Nogol-e-Sadat, M., 1993. 1:1,000,000 tectonic maps of Iran. Department of Iranian Geological Center, Tehran, Iran.

Pomar, L., Obrador, A., Westphal, H., 2002. Sub-wavebase crossbedded grainstones on a distally steepened carbonate ramp, Upper Miocene, Menorca, Spain Sedimentology, 49, 139-169.

Pomar, L., Hallock, P., 2007. Changes in coral-reef structure through the Miocene in the Mediterranean province: Adaptive versus environmental influence Geology, 35, 899. DOI: 10.1130/g24034a.1 
Rahiminejad, A.H., Nouradini, M., Yazdi, M., 2016. Palaeoenvironmental analysis of scleractinian reef corals from the Oligo-Miocene Qom Formation in the Vartun section (northeastern Esfahan, central Iran) Historical Biology, 29, 384-394. DOI: 10.1080/08912963.2016.1167201

Reuter, M., Piller, W.E., Harzhauser, M., Mandic, O., Berning, B., Rögl, F, Kroh, A., Aubry, M.P., Wielandt-Schuster, U., Hamedani, A., 2009. The Oligo-/Miocene Qom Formation (Iran): evidence for an early Burdigalian restriction of the Tethyan Seaway and closure of its Iranian gateways. International Journal of Earth Sciences, 98, 627-650. DOI: 10.1007/s00531-007-0269-9

Schuster, F., Wielandt, U., 1999. Oligocene and Early Miocene coral faunas from Iran: palaeoecology and palaeobiogeography. International Journal of Earth Sciences, 88, 571-581.

Schuster, F, 2002. Taxonomy of Oligocene to Early Miocene scleractinian corals from Iran, Egypt, Turkey, and Greece. Schweizerbart, 161pp.

Stocklin, J., 1968. Structural history and tectonics of Iran. a review. American Association Petrolium Geology Bulletin, 52, 1229-1258.

Wallace, C.C., Rosen, B.R., 2006. Diverse staghorn corals (Acropora) in high-latitude Eocene assemblages: implications for the evolution of modern diversity patterns of reef corals. Proceedings Biological sciences, The Royal Society, 273, 975982. DOI: $10.1098 /$ rspb.2005.3307
Wallace, C.C., Bosellini, FR., 2014. Acropora (Scleractinia) from the Oligocene and Miocene of Europe: species longevity, origination and turnover following the Eocene-Oligocene transition. Journal of Systematic Palaeontology, 13, 447-469. DOI: 10.1080/14772019.2014.930525

Westphal, H., Munnecke, A., 2003. Limestone-marl alternations: A warm-water phenomenon? Geology, 31, 263-266.

Westphal, H., 2006. Limestone-marl alternations as environmental archives and the role of early diagenesis: a critical review. International Journal of Earth Sciences, 95, 947-961.

Wilson, J.J., Al-Sofyani, A.A., Marimuthu, N., 2017. Current biodiversity and ecological status of scleractinian corals of Sharm Obhur, Jeddah, Saudi Arabian coast of the Red Sea. Marine Biodiversity, 47, 1111-1121. DOI: 10.1007/s12526017-0784-2

Yazdi, M., Shirazi, M.P., Rahiminejad, A.H., Motavalipoor, R., 2012. Paleobathymetry and paleoecology of colonial corals from the Oligocene-early Miocene (?) Qom Formation (Dizlu area, central Iran). Carbonates and Evaporites, 27, 395-405. DOI: $10.1007 / \mathrm{s} 13146-012-0122-5$

Zamani, A., Afghah, M., Jafarzade, N., 2010. Tectenostratigraphic of the Qom Formation (Centeral Iran). Iran, Paper presented at the $1^{\text {st }}$ International Applied Geological Congress, Islamic Azad University Mashad Branch, 26-8.

\section{Manuscript received May 2020; \\ revision accepted September 2021; published Online January 2022.}




\section{APPENDIX I}
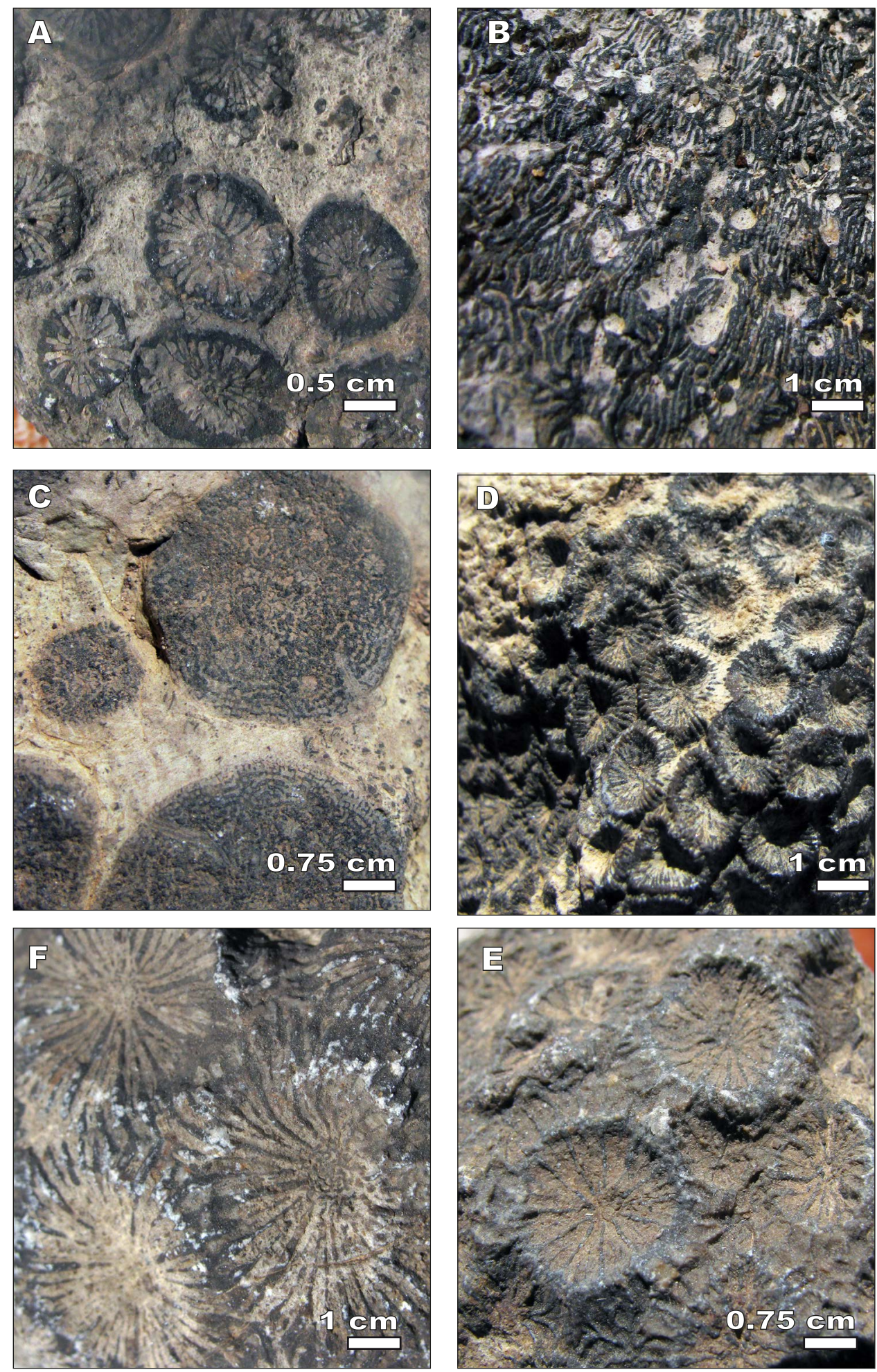

FIGURE I. Photograph of A) Agathiphyllia sp.; B) Cyathoseris cf. radiata; C) Acropora sp.; D) Antiguastrea lucasiana; E) Favia cylindracea; F) Agathiphyllia gregaria. 

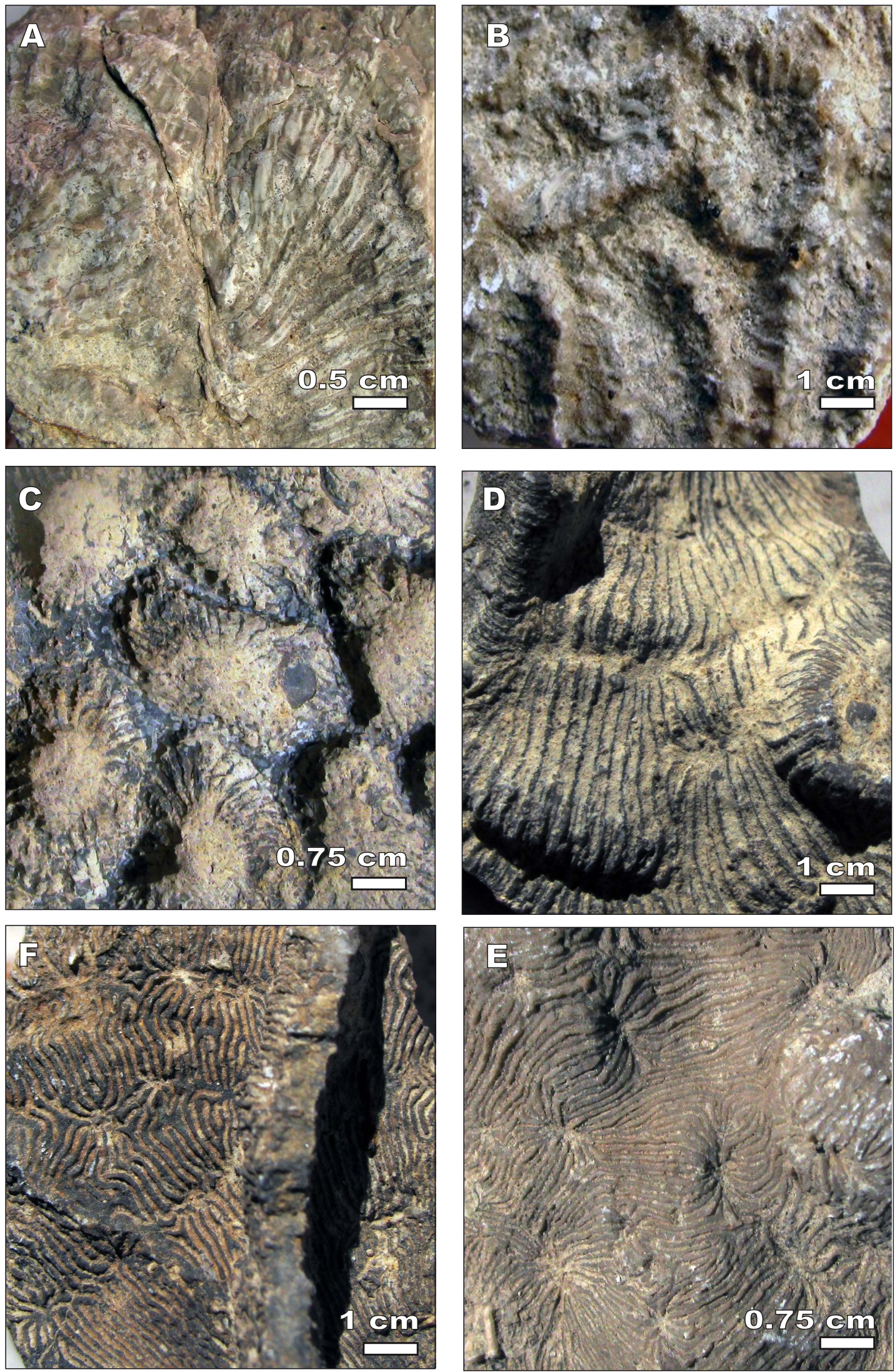

FIGURE II. Photograph of A) Ceriosmilia iranica; B) Hydnophyllia stellate; C) Favites neglecta; D) Cyathoseris sp1., E, F) Cyathoseris sp2. 

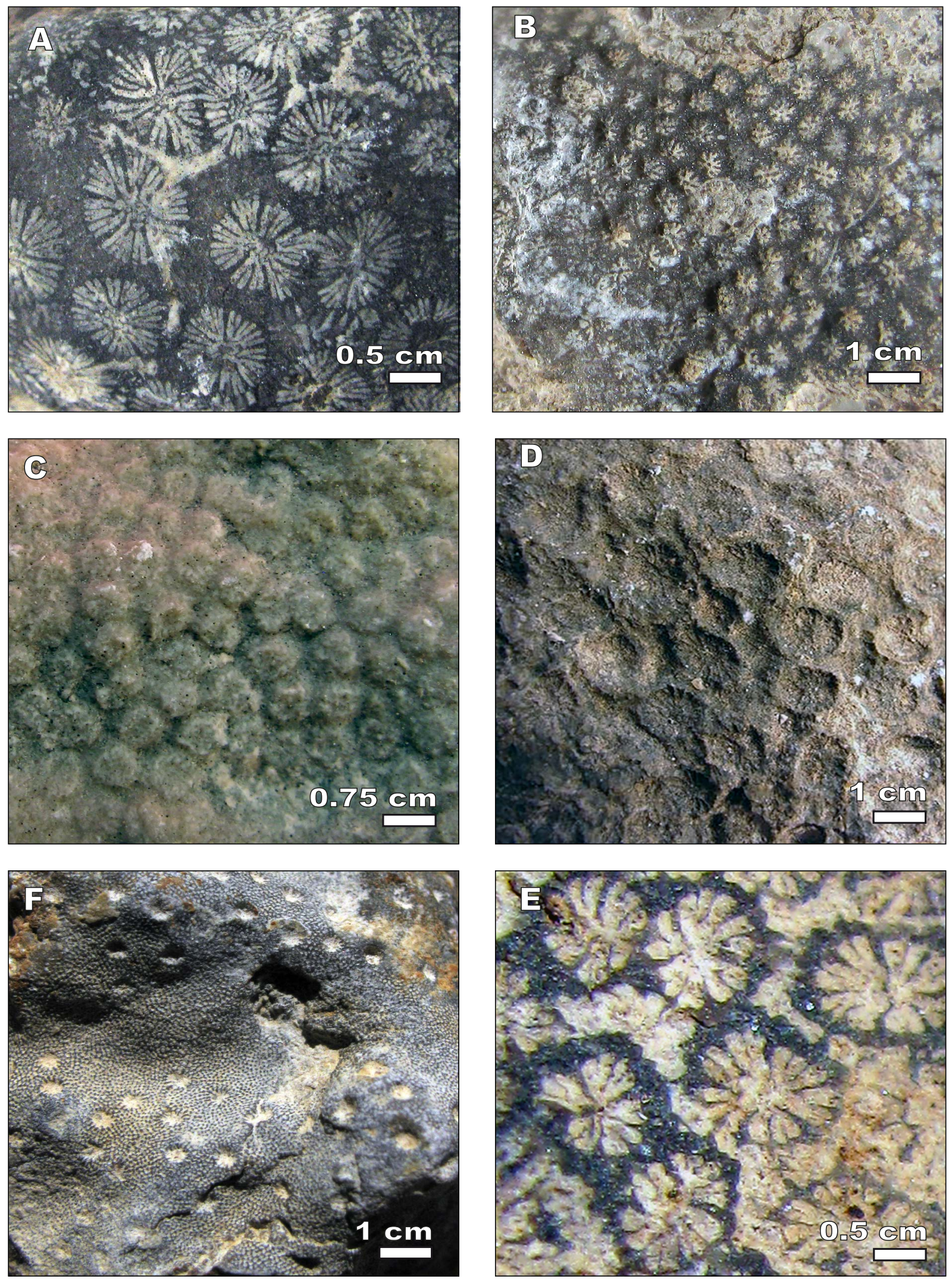

FIGURE III. Photograph of A) Septastrea sp.; B) Platycoenia iranica; C) Lepastrea sp.; D) Simplastrea sp.' E) Stylophora thirsiformis; F) Tarbellastrea carryensis. 

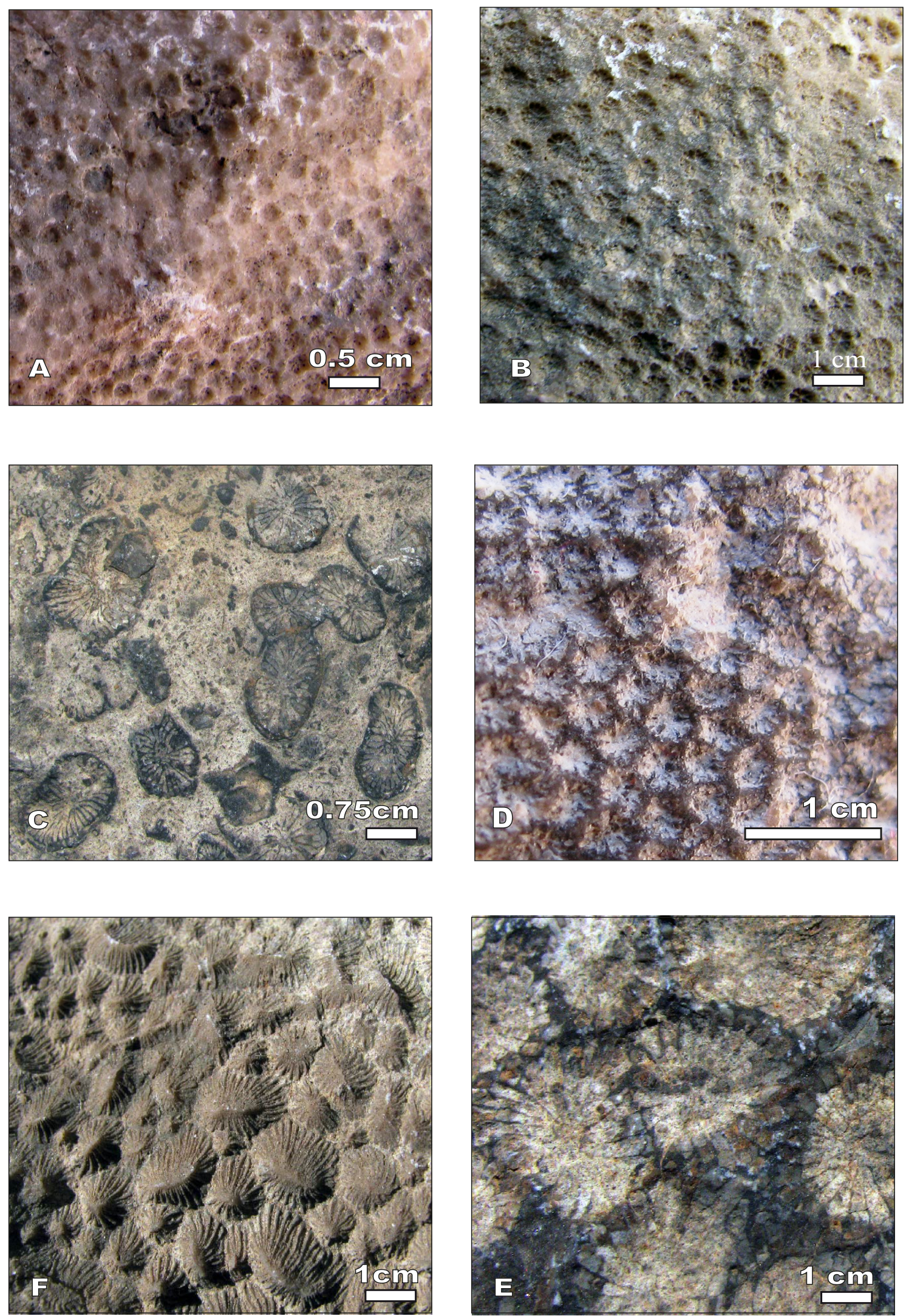

FIGURE IV. Photograph of A) Goniastrea sp.; B) Astrocoenia nana; C) Caulastrea pseudoflabellum; D) Alveopora SP.; E) Hydnophora rudis; F) Favites sp. 

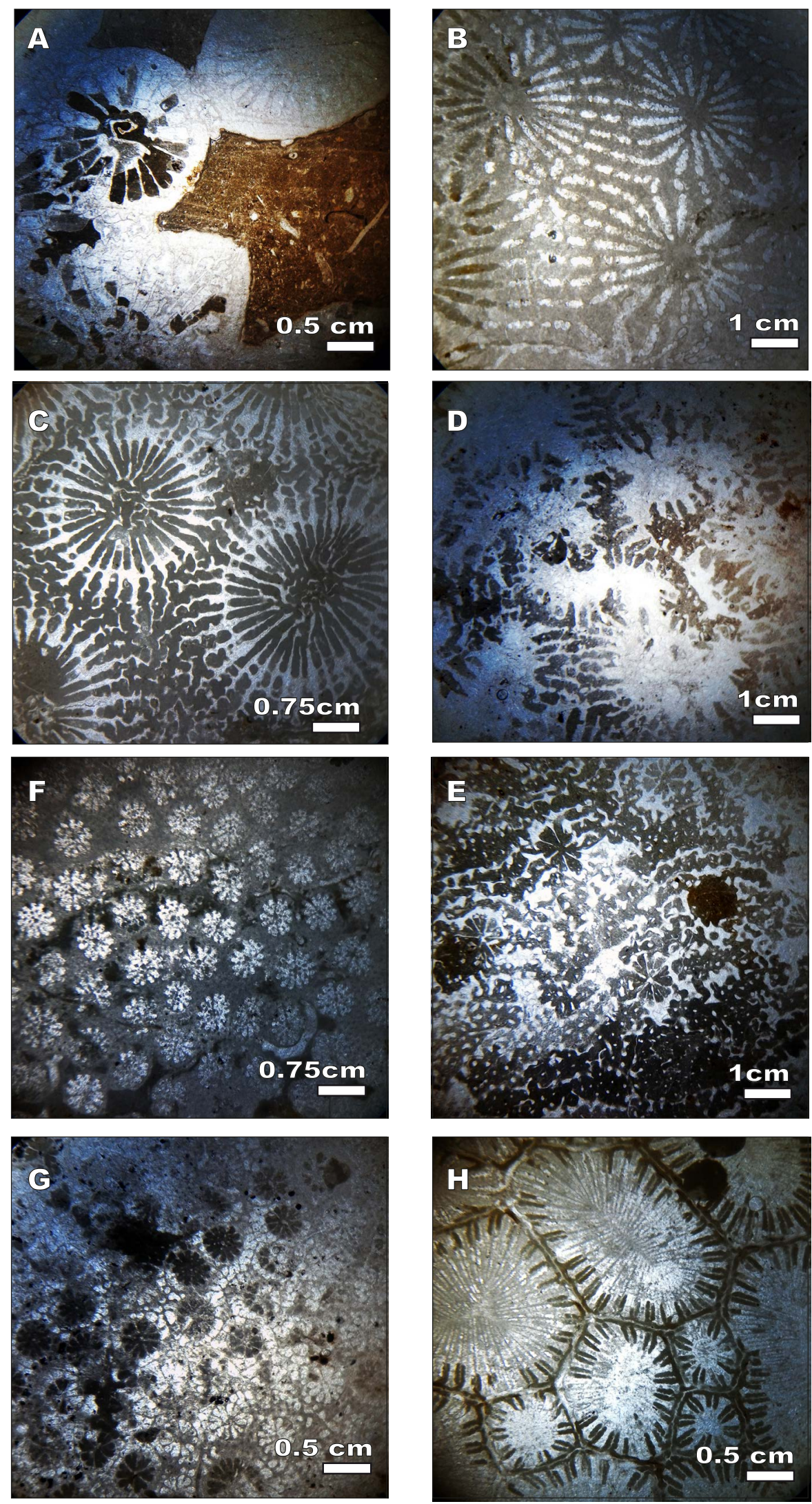

FIGURE V. Microphotograp of A) Astrangia persica; B) Favia cylindracea; C) Agathiphyllia gregaria; D) Hydnophyllia stellate; E) Platycoenia iranica; F) Stylophora thirsiformis; G) Astrocoenia nana; H) Hydnophora rudis. 